INVITED COMMENTARY

\title{
Prediction of postpartum thyroiditis
}

\author{
John H Lazarus \\ Department of Medicine, University of Wales College of Medicine, Cardiff CF64 2XX, UK
}

Postpartum thyroid dysfunction (PPTD) is characterised by transient hyperthyroidism occurring about 14 weeks postpartum, followed by transient hypothyroidism that presents at 19 weeks (1-3). Hyper- or hypothyroidism may occur alone. The condition, a destructive thyroiditis, predominantly occurs in patients with positive titres of thyroid peroxidase (TPO) auto-antibody (the microsomal antibody) seen in $10 \%$ of women at approximately 16 weeks gestation (4). The titre of these antibodies is known to decrease during gestation, but increases dramatically in the postpartum period (5). However, only about $50 \%$ of women found to be TPO antibody positive during pregnancy will develop PPTD. Some cases of PPTD have occurred in the absence of TPO antibodies, suggesting a non-immune cause, which is, as yet, unknown. Although the clinical manifestations of the hyperthyroid state are not usually severe, the same cannot be said for the hypothyroid condition that may be evident clinically and responds to thyroxine. In addition, there is evidence that, in $25-30 \%$ of hypothyroid postpartum women, the hypothyroidism becomes permanent after 1 year (6) and there is a further development of thyroid dysfunction in those women who were initally euthyroid after a transient attack of PPTD (7). Despite these facts, PPTD has not been as widely recognised as it might have been (8), and the clinical symptomatology has been considered to be mild. The condition has been described in many countries and has been reviewed $(9,10)$. Most reports have described relatively small numbers of patients who were followed over short periods of time. This has created a problem in defining the incidence of the condition, although it is now accepted that it occurs in 5-9\% of women during the first 1 year postpartum (11). There is also evidence that the presence of TPO antibodies, detected in the first trimester, is associated with a greater incidence of postpartum depressive symptomatology, independent of thyroid function $(12,13)$.

Because of the clinical associations of TPO antibodies in the setting of pregnancy, it is important to assess formally the predictive value, as a screening test, of measuring these antibodies during pregnancy. Kuijpens et al. (14) report, in this issue of the European Journal of Endocrinology, the findings of their study in which they examined this question by looking at the timing of TPO antibody testing and investigating whether other putative determinants of PPTD could improve the predictive power of TPO antibody. In this prospective study of 310 women, 291 were analysed and, interestingly, of 15 women with PPTD, only 10 had TPO antibodies. A high titre of TPO antibodies was found at 12 weeks gestation, and similar values were noted during the postpartum period. The well-known decrease in antibody titre during gestation was also confirmed. The authors concluded that the predictive value of measuring TPO antibodies as a screening procedure during gestation was $0.38-0.80$ (depending on the timing of testing) and increased slightly when smoking habits were taken into account. Thus, in their hands, a maximum of $67 \%$ of cases of PPTD can be predicted by the presence of TPO antibodies in gestation. As noted above, however, only $50 \%$ of TPO antibody positive women develop thyroid dysfunction postpartum, making the potential predictive power of TPO antibody for the total number of PPTD cases about $33 \%$ (taking into account the antibody negative patients).

An important clinical question, which has significant health care cost implications, is whether women should be routinely screened antenatally for TPO antibodies, as previously suggested $(15,16)$. A costbenefit analysis must take into account many factors, including the crude financial costs, the potential for inducing maternal anxiety about yet another antenatal screening test, and the evidence that any intervention resulting from the test would affect outcome. Although some of these questions have not been answered to the satisfaction of all (17), there are good data indicating the natural history of autoimmune PPTD (18). Considerable morbidity may result from unrecognised transient hypothyroidism, which is increased if the condition becomes permanent. It is quite probable that targeting those $10 \%$ of women who are TPO antibody positive antenatally, to receive postnatal thyroid evaluation, will be cost effective when quality of life analysis is considered. However, in order to improve the predictive value of the antibody test other measures such as serum thyroglobulin estimation (19), ultrasonic determination of thyroid volume (20) and assessment of TPO activation of complement (21) have been proposed. In addition, screening for TPO antibodies may be useful as a potential marker of impaired child development (22). A further prospective trial is indicated to build on the findings of Kuijpens and his colleagues. 


\section{References}

1 Amino N, Miyai KJ, Onishi T, Hashimoto T \& Arai K. Transient hypothyroidism after delivery in autoimmune thyroiditis. Journal of Clinical Endocrinology and Metabolism 197642 296-301.

2 Ginsberg J \& Walfish PG. Postpartum transient thyrotoxicosis with painless thyroiditis. Lancet 19771 1125-1128.

3 Amino N, Iwatani Y, Tamaki H, Mori H, Aozasa M \& Miyai K. Postpartum autoimmune thyroid syndromes. In Autoimmunity and the Thyroid, pp 289-314. Eds PG Walfish, JR Wall \& R Volpe. London: Academic Press, 1985.

4 Lazarus JH, Hall R, Othman S, Parkes AB, Richards CJ, McCulloch B et al. The clinical spectrum of postpartum thyroid disease. Quarterly Journal of Medicine 199689 429-435.

5 Fung HYM, Kologlu M, Collison K, John R, Richards CJ, Hall R et al. Postpartum thyroid dysfunction in Mid Glamorgan. British Medical Journal $1988296241-244$.

6 Othman S, Phillips DIW, Parkes AB, Richards CJ, Harris B, Fung H et al. A long-term follow-up of postpartum thyroiditis. Clinical Endocrinology 199032 559-564.

7 Premawardhana LDKE, Lazarus JH, Adams H \& Parkes AB. Abnormalities of thyroid function and morphology 7-10 years after postpartum thyroid dysfunction [PPTD]. Journal of Endocrinological Investigation 19961974 (abstract 147).

8 Smallridge RC. Postpartum thyroid dysfunction: a frequently undiagnosed endocrine disorder. Endocrinologist 19966 44-50.

9 Stagnaro-Green A. Postpartum thyroiditis: prevalence, etiology and clinical implications. Thyroid Today 1993 XVI 1-11.

10 Walfish PG, Meyerson J, Provias JP, Vargas MT \& Papsin FR. Prevalence and characteristics of post-partum thyroid dysfunction: results of a survey from Toronto, Canada. Journal of Endocrinological Investigation 199215 265-272.

11 Gerstein HC. How common is postpartum thyroiditis? A methodologic overview of the literature. Archives of Internal Medicine 1990150 1397-1400.

12 Harris B, Othman S, Davies J, Weppner GJ, Richards CJ, Newcombe RG et al. Association between postpartum thyroid dysfunction and thyroid antibodies and depression. British Medical Journal 1992305 152-156.
13 Pop VJM, de Rooy HAM, Vader HL, van der Heide D, van Son MM \& Komproe IH. Microsomal antibodies during gestation in relation to postpartum thyroid dysfunction and depression. Acta Endocrinologica 1993129 26-30.

14 Kuijpens JL, Pop VJ, Vader HL, Drexhage HA \& Wiersinga WM. Prediction of post partum thyroid dysfunction: can it be improved? European Journal of Endocrinology 1998139 36-43.

15 Hayslip CC, Fein HG, O'Donnell VM, Friedman DS, Klein TA, Smallridge RC. The value of serum antimicrosomal antibody testing in screening for symptomatic postpartum thyroid dysfunction. American Journal of Obstetrics and Gynecology 1988159 203-209.

16 Solomon BL, Fein HG \& Smallridge RC. Usefulness of antimicrosomal antibody titers in the diagnosis and treatment of postpartum thyroiditis. Journal of Family Practice 199336 177-182.

17 Ball S. Antenatal screening of thyroid antibodies. Lancet 1996 348 906-907.

18 Hall R. Pregnancy and autoimmune endocrine disease. Bailliere's Clinical Endocrinology and Metabolism 1995 9 137-155.

19 Parkes AB, Black EG, Adams H, John R, Richards CJ, Hall R et al. Serum thyroglobulin - an early indicator of autoimmune postpartum thyroid disease. Clinical Endocrinology 1994 41 9-14.

20 Adams H, Jones MC, Othman S, Lazarus JH, Parkes AB, Hall R et al. The sonographic appearances in postpartum thyroiditis. Clinical Radiology 199245 311-318.

21 Parkes AB, Othman S, Hall R, John R \& Lazarus JH. The role of complement in the pathogenesis of postpartum thyroiditis: relationship between complement activation and disease presentation and progression. European Journal of Endocrinology $1995133210-215$

22 Pop VJ, de Vries E, van Baar AL, Waelkens JJ, de Rooy HA, Horsten $\mathrm{M}$ et al. Maternal thyroid peroxidase antibodies during pregnancy: a marker of impaired child development. Journal of Clinical Endocrinology and Metabolism $1995803561-3566$.

Received 16 March 1998

Accepted 16 March 1998 